\title{
Marcin Poprawa, Telewizyjne debaty polityków jako przykład dyskursu publicznego, Towarzystwo Autorów i Wydawców Prac Naukowych Universitas, Kraków 2009, ss. 316
}

Marcin Poprawa jest jednym z badaczy zajmujących się współczesnym dyskursem medialnym i zagadnieniami komunikacji politycznej. Ze względu na swoje filologiczne wykształcenie szczególny nacisk kładzie na perspektywę językoznawczą omawianych zagadnień. W pracy naukowej skupia się na języku polityki, ideologicznych aspektach komunikacji oraz perswazji i manipulacji w dyskursie, w ujęciu zarówno synchronicznym, jak i diachronicznym.

W swojej książce prezentuje sposoby komunikacji polityków i dziennikarzy podczas wystapień w telewizyjnych programach publicystycznych. Przedstawia aktorów telewizyjnej publicystyki oraz unaocznia znaczenie autoprezentacji w tego typu programach.

Celem pracy jest opisanie, ,jakie są formy teatralizacji telewizyjnego spektaklu z udziałem polityków i dziennikarzy oraz jakie kategorie zachowań komunikacyjnych wyznaczają granice współczesnego dyskursu publicznego, którego jedną z najbardziej symbolicznych, atrakcyjnych i nośnych medialnie form okazują się telewizyjne debaty polityków" (s. 12). Autor stara się przedstawić z perspektywy zarówno teoretycznej, jak i empirycznej strategie komunikacyjne, tekstowe oraz pragmatyczne stosowane przez polityków (oraz dziennikarzy) podczas wystąpień publicznych. Wszystko opisane jest w kontekście zagadnień dyskursu telewizyjnego, czy raczej - szerzej - publicznego, ale w bezpośrednim związku z poetyką telewizyjnego wydarzenia komunikacyjnego o określonych parametrach i funkcji.

Praca składa się ze Wstępu (s. 11-18), ośmiu rozdziałów: Dyskurs publiczny-ujęcie teoretyczne (s. 19-38), Język polityki-stanowiska badawcze i wspótczesne tendencje rozwojowe (s. 39-52), Język telewizji na tle teorii komunikacji (s. 53-73), Aktorzy telewizyjnej publicystyki i ich role w dyskursie (s. 74-142), 
Autoprezentacja w telewizyjnych dyskusjach polityków (s. 143-189), Autoprezentacja w świetle pragmatyki językowej (s. 190-212), Autoprezentacja a zmiany telewizyjnego uktadu komunikacyjnego (s. 213-226), Analiza konwersacyjna telewizyjnej debaty politycznej. Studium przypadku (s. 227-263), a także Zakończenia (s. 264-266), Aneksu (s. 267-290) oraz Bibliografii (s. 291-312).

Zawartość merytoryczną można podzielić na trzy zasadnicze części: zagadnienia teoretyczne, opis poszczególnych kategorii zachowań oraz globalna analiza wybranej debaty politycznej. W części teoretycznej autor charakteryzuje tło komunikacyjne omawianych problemów, czyli język telewizji i polityki, a także przedstawia zjawisko dyskursu i jego wszechstronność oraz interdyscyplinarny charakter. We właściwej części analitycznej, w kórej możemy wyróżnić dwa główne elementy: przedstawienie poszczególnych ról komunikacyjnych oraz wnikliwy opis strategii autoprezentacji, najwięcej uwagi poświęcono deskrypcji technik autoprezentacji polityków.

W rozdziale dotyczącym aktorów telewizyjnej publicystyki autor prezentuje odbiorcę telewizyjnego, warianty zachowań polityków oraz formy reakcji dziennikarzy prowadzących. Celem tej części jest zaprezentowanie ról społecznych uczestników zdarzenia komunikacyjnego (na podstawie wykorzystywanych strategii perswazji werbalnie zakłócających rozmowę, a ukierunkowanych na pozyskanie odbiorcy - audytorium). Autor dokonuje tego przez charakterystykę poszczególnych aktów mowy wraz z opisem tła dyskursywnego. Przy wymienianiu symbolicznych i konwersacyjnych ról aktorów politycznych opisuje typowe dla nich cechy zachowań językowych, przedstawiając poszczególne konstrukcje i środki językowe, a także figury retoryczne. Ukazując strategie komunikacyjne stosowane przez dziennikarzy, skupia się natomiast na zaczepkach słownych, konstrukcji pytań (z wyodrębnieniem pytań pozornych) oraz specyfice deklaratywnych i apelatywnych aktów mowy.

W częściach dotyczących autoprezentacji autor omawia zjawisko z perspektywy psychologicznej, medioznawczej, językowej oraz komunikacyjnej. Stawia tezę, że działania komunikacyjne polityków są skierowane na zjednanie sobie audytorium telewizyjnego, a osiągane to jest dzięki różnorodnym formom autokreacji, która ukryta jest w wypowiedziach uczestników debat. $\mathrm{Z}$ tego względu mocno wyeksponowane są strona językowa i aspekt filologiczny: zjawiska wyzwalające autoprezentację, typowe środki leksykalne oraz grupy leksemów, realizacje zdań ze słownictwem normatywnym, grupy treści fakultatywnych (konotowanych i nakłaniania), metafory, wartości pozytywne i negatywne w formie aktów rady czy negatywnych metonimii, leksemy obrazujące rzeczywistość potępianą oraz ekspresywizmy. Niezwykle ważne jest to, że każda z części analitycznych ilustrowana jest licznymi przykładami, które ze względu na dużą różnorodność ułatwiają lekturę książki. Autor najwięcej 
miejsca poświęca analizie poszczególnych aktów mowy, wchodząc bardziej szczegółowo w pewne zagadnienia.

W ostatnim rozdziale przeprowadzona zostaje analiza konwersacyjna debaty telewizyjnej na konkretnym przykładzie, która również uzupełnia wcześniejsze opisy tego gatunku o strukturę globalną i zakłócenia mające wpływ na kształt gatunku. Globalna organizacja telewizyjnej debaty polityków zostaje ustrukturyzowana przez autora przez podział na typy zachowań oraz fazy debaty. W każdej z trzech faz (otwarcie, wyznaczanie tematów, zakończenie) wymieniane są charakterystyczne zabiegi komunikacyjne ukazane na konkretnych przykładach, takie jak: $w$ fazie otwarcia - określenie intencji, rozkład tematów, funkcja i struktura kognitywna, w fazie wyznaczania tematów - przykłady emocjonalnych reakcji, strategie komunikacyjne i zabiegi przerywające dyskusję. W drugiej części zaś - dotyczącej zakłóceń komunikacyjnych - autor skupia się na poszczególnych technikach, strategiach i mechanizmach językowych oraz tekstowych rozbijających strukturę konwersacyjną wypowiedzi.

Wnikliwa analiza i interpretacja materiału pozwalają autorowi pokazać ogólne prawidłowości debat publicznych. Niezwykle interesujący jest sposób opisania zachowań komunikacyjnych, które pomimo surowych analiz językowych dzięki odniesieniu do szerszego kontekstu wydarzenia komunikacyjnego zyskują charakter interdyscyplinarny i pozwalają umiejscowić konkretne strategie autoprezentacyjne w dyskursie publicznym.

W części teoretycznej - poprzedzającej analizy zachowań komunikacyjnych - opisane zostały dotychczasowe stanowiska badawcze powiazzanych zagadnień oraz poszczególne perspektywy tła dyskursywnego. Zabrakło wprowadzenia do samej historii debat politycznych i modyfikacji tego gatunku na przestrzeni wieków. Bardzo mocno wyeksponowane zostały zaś strategie autoprezentacji, co bardziej uwydatniło funkcję debat telewizyjnych niż sam gatunek publicystyczny (znalazło to uzasadnienie w tle dyskursywnym). Dopiero ostatni rozdział pokazuje zastosowanie poszczególnych strategii autoprezentacji w debacie politycznej.

Aspekt językowy w opisywanej książce został ujęty w szerokiej charakterystyce oraz analizie aktów mowy i ogólnej analizie dyskursywnej. Konkretne konstrukcje czy formy językowe zostały przywołane jedynie w pewnych strategiach wypowiedzi. Znaczną część stanowią zaś opisy sytuacji komunikacyjnej i tła dyskursywnego. Niemniej jednak warto zwrócić uwage na dużą liczbę różnorodnych przykładów obecnych na każdym etapie analiz dyskursywnych.

Największe zaskoczenie wywołuje fakt, iż w części poświęconej studium przypadku wybranej debaty telewizyjnej analiza nie następuje według kolejności wypowiedzi poszczególnych uczestników, ale według wybranych przez 
autora czynników kształtujących globalną strukturę tekstu oraz zakłócenia w komunikacji. Idealnym dopełnieniem i podsumowaniem części analitycznej byłoby omówienie fragmentu debaty z wyszczególnieniem, w jaki sposób poszczególne strategie i zachowania komunikacyjne wzajemnie się nakładają i uzupełniają. Uwidoczniłoby to złożoność zjawiska teatralizacji debat politycznych.

Uzupełnieniem charakterystyki dyskursu publicznego na przykładzie debat telewizyjnych, czyli rozdziałów I-VIII, jest Aneks zawierający analizę konwersacyjną z „wieloaspektowym zapisem procesów konwersacyjnych, uwzględniający poszczególne jednostki lokalnej organizacji wypowiedzi (przepływ tur, nakładanie się wypowiedzi, zrywanie transferu, przejmowanie głosu) wraz z deskrypcją elementów pragmalingwistycznych i znaczących sygnałów proksemicznych i kinezycznych" (s. 16). Jest to niewatpliwie uzupełnienie rozdziału VIII, ale wciąż pozostawia niedosyt, gdyż zarówno studium przypadku, czyli struktura globalna i zakłócenia komunikacyjne (rozdział VIII), jak i charakterystyka poszczególnych strategii nie doczekały się wspólnego zestawienia, najlepiej na podstawie analizy konwersacyjnej zawartej w Aneksie.

Książka została napisana przyjaznym czytelnikowi językiem, a forma przedstawiania kolejnych zagadnień sprzyja rozumieniu problematyki współczesnego dyskursu publicystycznego. Chociaż podstawą do analiz dyskursywnych w dużej mierze są komunikaty językowe, interdyscyplinarny charakter tej pozycji sprzyja wykorzystywaniu jej w różnych badaniach. Ważne jest zatem, że będzie ona zrozumiała dla studenta zarówno językoznawstwa, jak i dziennikarstwa, czy też socjologii lub politologii. Na uwagę zasługuje również obszerna i bardzo precyzyjnie sporządzona bibliografia, która zawiera istotne opracowania, szczególnie dotyczące zagadnień językowych związanych z podejmowaną problematyka.

Opisywana książka jest interesująca z kilku powodów. Oprócz przedstawienia strony językowej, w którym poszczególne strategie i zachowania komunikacyjne zostały poddane wnikliwej analizie, scharakteryzowane zostały także te zabiegi w szerszym kontekście dyskursu publicznego. Ponadto podkreślenie roli autoprezentacji zwraca uwagę na zupełnie nowy aspekt komunikacji politycznej, czyli reklamę polityczną.

Wniosek z analiz Marcina Poprawy jest zatem taki, że debata jako forma zaistnienia na forum telewizyjnym służy głównie celom autoprezentacyjnym. Autoprezentacja zaś jest częścią reklamy politycznej, która odsyła do marketingu politycznego oraz szeroko rozumianych zagadnień public relations. $\mathrm{Pu}-$ blicystyka i debaty polityczne stały się znakomitą okazją do promocji własnej osoby oraz reprezentowanego stanowiska politycznego. 
Celem autora było przedstawienie formy teatralizacji oraz kategorii zachowań komunikacyjnych wyznaczających granice współczesnego dyskursu publicznego i zostało to w książce zrealizowane. Wielość strategii komunikacyjnych, związanych zwłaszcza z autoprezentacja, i ich dokładny opis stanowią doskonały przykład teatralizacji tego gatunku publicystycznego, a charakterystyka językowa wybranych zachowań komunikacyjnych uzupełnia całość analiz, podkreślając dyskursywność opisywanego zjawiska.

Katarzyna Wardzała 